\title{
Hands in Dickens: Neuroscience and Interpretation
}

\author{
- ONOCN \\ NEIL FORSYTH \\ Université de Lausanne
}

$\mathrm{I}$ $\mathrm{n}$ an essay for The Guardian of March 1, 2003, entitled "Hands that mould the imagination," the well-known novelist Sarah Waters, author of Tipping the Velvet and Fingersmith, describes in some detail how her memory of Molly's hands in Great Expectations had stayed with her and gradually came back to consciousness as she wrote one of her own novels, Affinity. The piece is reprinted on the Penguin website. ${ }^{1}$ It begins as follows:

A curious thing happened to me while I was writing my second novel, Affinity. The novel is set in the 1860s, partly in a women's prison, partly in an upper-middle-class home. It's a rather gothic novel, full of twists and reversals, and for the purposes of theme and plot there's a foregrounding at certain moments of hands - the drawing of attention, for example, to the strong, possibly sinister, hands of at least two female characters. As I was putting the book together, I was dimly aware that the hands I was describing were recalling some other hands to me; and at last I realised whose those were. They were the scarred and powerful hands of Jaggers's housekeeper, Molly, in Great Expectations - that 'wild beast tamed,' as Wemmick dubs her. His phrase is telling: Molly's hands are over-determined in Dickens's text because of the secret to which they gesture - the final secret of the book, the secret of Estella's criminal origins - but I'd always been impressed and unsettled by what seemed to me to be the novel's frankly fetishistic treatment of them, the oddly magnified space they occupy within its narrative economy. Now, writing Affinity, striving after a fetishized and magnified literary effect of my own, I realised that they had lodged themselves in my imagination, much as a splinter would; and, like a splinter, they had worked their way to the surface of my mind as part of a creative process over which, it seemed to me, I had disquietingly little control.

1 http://www.penguinclassics.com.au/resources/SWonGE. 
That splinter in Waters's imagination is a fine metaphor for the creative mind at work. More than that, it is characteristic of the way some of us, perhaps all, respond to the details of what we read. Memory, not always conscious, overlaps with imagination as we put ourselves into the situations described or evoked. We may not be going on to write a new story for ourselves, but discoveries in neuroscience during the past fifteen years, especially the controversy over mirror neurons, have shown that, if we respond at all to what we read, we are, however minutely, imitating what is happening in the text. This has come to be called "simulation." ${ }^{2}$ Those hands in Dickens are indeed rather special but one way to understand what is so impressive about them, and why Waters remembered them, is to see how skillfully Dickens activates for us their sheer physicality. "Fetishized and magnified" they may be, but Molly's hands form part of a larger pattern within the novel, and their importance also evokes other and similarly important hands elsewhere in Dickens's fiction.

The incident to which Waters is referring occurs in chapter 26. Jaggers is "leaning back in his chair biting the side of his forefinger" when he offers the young men assembled at his table a demonstration of his power over the housekeeper. "Suddenly, he clapped his large hand on the housekeeper's, like a trap, as she stretched it across the table. So suddenly and smartly did he do this, that we all stopped in our foolish contention." Overcoming her reluctance, he insists that she show her hands:

"Molly," said Mr. Jaggers, not looking at her, but obstinately looking at the opposite side of the room, "let them see both your wrists. Show them. Come!"

He took his hand from hers, and turned that wrist up on the table. She brought her other hand from behind her, and held the two out side by side. The last wrist was much disfigured - deeply seamed and scarred across and across. [...]

"There's power here," said Mr. Jaggers, coolly tracing out the sinews with his forefinger. "Very few men have the power of wrist that this woman has. It's remarkable what mere force of grip there is in these hands. I have had occasion to notice many hands; but I never saw stronger in that respect, man's or woman's, than these." (166; ch. 26)

2 For a good summary of recent research, see Guillemette Bolens (11-16). She shows how "this type of simulation, often termed motor resonance, is the process by which action observation activates the same neural substrates as those recruited when a perceiver performs an action by themselves." For the controversy, see Raymond Tallis. For a different and specific way in which the ability to read may be mapped in the brain, see the excellent Guardian neuroscience blogger, Mo Costandi at http:// www.theguardian.com/science/neurophilosophy/2014/nov/17/major-brain-pathwayrediscovered, reporting on Yeatman.

Vol. 32, No. 3, September 2015 
Part of the reason for the power of the scene is the presence of Jaggers's own hand, which implicitly gains in strength from what he says about Molly's grip as he grasps hers. Moreover he traces her sinews with his forefinger. The detail repeats what was said a few lines before about Jaggers "biting the side of his forefinger" - a gesture we have seen previously in the novel. A pattern of meaning is emerging in the novel through the repetition of hand gestures.

This little scene is also enhanced by a curious rather Gothic association that Pip, the narrator, makes with Molly.

She was a woman of about forty, I supposed - but I may have thought her younger than she was. Rather tall, of a lithe nimble figure, extremely pale, with large faded-blue eyes, and a quantity of streaming hair. I cannot say whether any diseased affection of the heart caused her lips to be parted as if she were panting, and her face to bear a curious expression of suddenness and flutter; but I know that I had been to see Macbeth at the theatre, a night or two before, and that her face looked to me as if it were all disturbed by fiery air, like the faces I had seen rise out of the Witches' caldron. [... ]

No other attendant than the housekeeper appeared. She set on every dish; and I always saw in her face, a face rising out of the caldron. Years afterwards, I made a dreadful likeness of that woman, by causing a face that had no other natural resemblance to it than it derived from flowing hair to pass behind a bowl of flaming spirits in a dark room. (165; ch. 26)

Perhaps there is a subsidiary, even subconscious, association with the Lady Macbeth of the sleep-walking scene, unable to wash the blood from her hands. In any case, Dickens clearly wants his reader to notice Molly, and he uses characteristic accumulation of specific detail to make her memorable. There is in fact no further reference to the creepy face rising out of a cauldron or the "bowl of flaming spirits in a dark room." The hands however come back more than once. There is a specific reason for this within the plot of the novel, the developing mystery that surrounds Estella's parentage. But what is significant for my purposes is the way the detail of the hands is evoked.

Charles R. Forker showed in a pioneering study many years ago that the novel is obsessed by hands: they almost take on a language of their own. There are some 450 uses of the word "hand" alone in the novel. Mrs. Joe rears her young brother Pip by hand (i.e. by using a feeding bottle, but also implicitly by beating him), and her heavy hand contrasts oddly enough with the blacksmith Joe's "great, good hand" (349; ch. 57). Dickens makes a good deal of comic fun out of Joe's efforts to learn to read and write, and indeed reading itself, introduced through the writing inscribed on Pip's parents' 
tombstones in the very first page of the novel, becomes itself a major theme. ${ }^{3}$ In that scene, Pip imagines his five little dead brothers as having "been born on their backs with their hands in their trousers-pockets" (9; ch. 1). Pip's first reaction to his meeting with Estella and her "taunting hand" (with which she slaps his face) is to feel shame at the coarseness of his hands (ch. 8). He now considers them "vulgar appendages." Orlick's "murderous hand" (318; ch. 53) does a lot of threatening in the scene at the sluice-gate, and in his terror Pip notices "the slightest action of his fingers." Indeed some of the hands take on a language of their own, so that it is finally by Mrs. Joe's drawing a picture of a hammer on a slate that Orlick is identified as her attacker. The list could go on. But all these references to hands do not only make up an aesthetically pleasing pattern as we experience the overall structure of the novel. They also work on us, if the theory of mirror neurons is correct, at the level of our sensations.

Since Forker's work, there have been further discussions of hands in this novel, ${ }^{4}$ of which the most thorough and interesting is that of Philip Capuano in the pages of this journal. He proposes a link with Darwin's Origin of Species, published the previous year (1859), and more generally with what he calls "a surging popular discourse about hands" in the midcentury. He points to the "urgently interrelated debates about evolution, class, and political economy" in which these references to hands participate. Suddenly it was no longer possible confidently to assume man's superiority to the animals when Darwin could assert that "the framework of bones is the same in the hand of a man, wing of a bat, fin of the porpoise, and leg of the horse" (387). Moreover the recent discovery of the gorilla, of which the British Zoological Society received its first specimen in 1858, made Victorian society acutely conscious of the possibilities inherent in what was already being called the "Missing Link." Capuano shows how the hand was becoming "a site where scientists, politicians and novelists alike looked for a paradoxical kinship with and divergence from the variously imagined 'lower orders' which dominate the cast of Great Expectations" (190 n.).

Capuano assumes that Molly is Irish, though the book says only that she may have gypsy blood (when Wemmick eventually tells her story in ch. 48). In any case Molly has, we learn in that same passage, strangled a woman twice her size with her bare hands. In the scene that Sarah Waters recalled from Dickens's text, Jaggers is making an implicit contrast between the

3 Martine Hennard Dutheil de la Rochère. “Great Expectations as Reading Lesson.” Dickens Quarterly 13:3 (1996): 164-74.

4 Norman Macleod reviews the various approaches. More recently Joseph P. Jordan has pointed to the recurrence of the many references to hands as a kind of unifying poetic device, much in the way that Forker had done. See also Bert G. Hornback, ch. 9, "Hands, Chains, Parts and Partings, Clicks." 
wild but tamed hands of Molly and his own "exceedingly dark complexion" and "correspondingly large hand" (68, ch 11). Jaggers's need to do so, and thus perhaps to conceal his own social origins, is also demonstrated by his constant ritual hand-washing, and with scented soap at that.

In the second part of the novel, Dickens extends the language of hands: he develops the ironic contrast between Pip's refined, gentleman's hands and those of Magwitch the convict, a contrast which is emphasized and then undermined when Pip's hands are burned in the fire. The irony is parallel to that which so improbably links the servant Molly's violent animality to Estella's refinement, beauty and leisure.

Capuano's "historicizing" argument is convincing, and it leads him to notice that Dickens highlights Pip's inability to comprehend the socioeconomic system on which the novel depends by his repeated failure to identify the link of Molly's hands and Estella's. But Capuano does not point out the obvious corollary of this failure. Even as Pip is not making the connection, Dickens is encouraging the reader to make it. In chapter 29, for example, Pip returns to Satis House at Miss Havisham's invitation, and there finds her sitting with "an elegant lady whom I had never seen." This lady looks archly at Pip and then he recognizes Estella. She gives him her hand, and a little later, when they go outside:

As my eyes followed her white hand, again the same dim suggestion that I could not possibly grasp, crossed me. My involuntary start occasioned her to lay her hand upon my arm. Instantly the ghost passed once more and was gone.

What was it? (183; ch. 29)

They go back indoors. Estella leaves him to talk with Miss Havisham, and suddenly he recognizes the scent of his guardian, Jaggers, in the room. Once again Jaggers is identified by his hands, though this time by means of the silk pocket handkerchief he always carries and flourishes as a way to intimidate. "Then he pushed Miss Havisham in her chair before him, with one of his large hands, and put the other in his trousers-pocket as if the pocket were full of secrets"(185). So here, within the same episode references to Jaggers's hands and Estella's occur within a few lines of each other.

The question - "What was the nameless shadow?" - repeatedly chills Pip each time he observes anything associated with Estella's hands, as he does at the end of chapter 32 when she waves to him from the window of a carriage (202). From all of these passages it is surely clear that Dickens expects his readers to make the identification between Molly and Estella before Pip does. He deliberately engages the reader in feeling the hands of the characters. And the means by which he does so is by lodging those sensual details of the hands, both Estella's and Molly's, in our imaginations as we read. 
Not only does the novel contain the repeated notices of Molly's hands that made such an impression on Waters, but there is also the recognition of Jaggers between chapters 11 and 18 (106) through his gesture of biting "the side of [his] great finger." Pip does make the connection (107), but the attentive reader is ahead of him. We first recognize Jaggers, and then wait for Pip to catch up. Similarly, though Pip does eventually realize that there is a reason for the similarity of Estella's hands to Molly's, the reader, following strong, even melodramatic hints like that "what was the nameless shadow?" will already have inferred that Molly is Estella's mother.

The hands in the novel gradually weave a pattern that Dickens clearly expects us to notice, and the sensual details by which he does so, we may now add, activate the ways our brains regularly respond to such language. Recent advances in neuroscience, especially the discovery of mirror neurons, have allowed us to understand our reactions as we read such scenes. The mirror neurons are nerve cells in our brains that vibrate however minutely when stimulated by what others do. What we call by the rather vague term "empathy" can be located in specific areas of the brain. 5 Seeing someone else in pain or joy can produce the same brain and body reaction as if we ourselves were experiencing the emotion, which is called "simulation." We learn to smile when mother smiles: we even smile inwardly - the phrase has real meaning. Cognitive sciences have been demonstrating through many and various experiments that we are impelled to move our own bodies, however slightly, by the movements of others, and - this is what is most remarkable - not only by seeing movements in others but even by looking at pictures or reading about them. The way we understand an action and respond to it (Jaggers biting his great forefinger, his grasping Molly's hands) is by simulating it in our own neuronal system.

There are in fact many significant hands in Dickens's fiction, from Fagin's dirty fingernails, the lily hands of Charity and Mercy Pecksniff, Captain Cuttle's remarkable hook, Stephen Blackpool's steady grasp, Thomas Gradgrind's "squarely pointing square forefinger," to the fat forefinger of Inspector Bucket, which "seems to rise to the dignity of a familiar demon." In each case, knowledge of recent cognitive research may help us appreciate the extraordinary impact of Dickens's texts on his readers. An especially illuminating example occurs in David Copperfield. Shaking someone's hand is a well codified social act suggesting solidarity, either in greeting or parting. In this passage (ch. 39), Dickens exploits and renders physical, for the reader, the conventional social act. Uriah Heep's dishonesty has procured power for himself within the establishment of his patron, Wickfeld (both firm and household). One evening after dinner the full extent of his sadism is revealed:

5 Gallese Vittorio, "The roots of empathy: the shared manifold hypothesis and the neural basis of intersubjectivity." Psychopathology 36 (2003) :171-80.

Vol. 32, No. 3, September 2015 
"We seldom see our present visitor, sir," he said, addressing Mr. Wickfield, sitting, such a contrast to him, at the end of the table, "and I should propose to give him welcome in another glass or two of wine, if you have no objections. Mr. Copperfield, your elth and appiness!"

I was obliged to make a show of taking the hand he stretched across to me; and then, with very different emotions, I took the hand of the broken gentleman, his partner. (486; ch. 39)

Each handshake immediately becomes a particular and significant gesture in itself, both exploiting and violating the social convention. After further conversation, David as narrator comments:

I pass over Mr. Wickfield's [...] consciousness of his own weakness, the ineffectual effort that he made against it; the struggle between his shame in Uriah's deportment, and his desire to conciliate him; the manifest exultation with which Uriah twisted and turned, and held him up before me. It made me sick at heart to see, and my hand recoils from writing it. $(486 ; \text { ch. } 39)^{6}$

Heep proposes the health of Agnes, Wickfield's daughter, and announces he wants to marry her. "No physical pain that her father's grey head could have borne, I think, could have been more terrible to me, than the mental endurance I saw compressed now within both his hands." Suddenly Wickfield explodes and attacks Heep.

"You had better stop him, Copperfield, if you can," cried Uriah, with his long forefinger pointing towards me. "He'll say something presently - mind you! - he'll be sorry to have said afterwards, and you'll be sorry to have heard!" [...]

"Oh, Trotwood, Trotwood!" [as he calls David] exclaimed Mr. Wickfield, wringing his hands. "What I have come down to be, since I first saw you in this house!" (487; ch. 39)

In this passage we are made to see the radical differences, and the rivalry, between the father and suitor, and between David and Heep, by what they do with their hands. Wickfield first holds his head in his hands, and then wrings them in despair: these are both conventional gestures in themselves, and are necessarily so represented here, since they express the ordinary humanity of Wickfield in contrast to the despicably serpentine Heep, pointing that extraordinary long forefinger at David. And in the midst of it all comes the sudden reference to David's own hand, recoiling in the very act of writing.

6 Hands in this novel have not received as much attention as they deserve. Even an essay about writing, by David Kellogg, does not mention this passage. 
Readers of David Copperfield have by now come to realize that Uriah Heep, repulsive though he is made to be, is a distorted reflection of David himself. He is almost the narrator's unconscious - partly because of a dream, partly through Heep's desire for Agnes, which David has not yet learned he also feels. The relation of the hands in the passage helps the reader to feel it, and also to understand why the narrator's hand explicitly recoils from writing at this key moment. The reader knows what he, David Copperfield, does not yet see, and cannot write. Behind him, Dickens, writing the passage, invites us to understand, if only indirectly. David's disgust has deeper psychological roots than he knows.

Neuroscience is not necessary for us to be able to interpret Dickens's quite clearly conscious play with the image of the hand in this scene. But our appreciation of an earlier scene, to which this one indirectly refers, may, I think, be increased in the light of the recent research into mirror neurons. In fact Dickens has already made the reader share the sensation of touching Heep's hand. When David first sees him, he notices immediately his long lank skeleton hand - and then comes the following passage. One evening, David returns from a walk:

As I came back, I saw Uriah Heep shutting up the office; and feeling friendly towards everybody, went in and spoke to him, and at parting, gave him my hand. But oh, what a clammy hand his was! as ghostly to the touch as to the sight! I rubbed mine afterwards, to warm it, and to rub his off.

It was such an uncomfortable hand, that, when I went to my room, it was still cold and wet upon my memory. Leaning out of the window, and seeing one of the faces on the beam-ends looking at me sideways, I fancied it was Uriah Heep got up there somehow, and shut him out in a hurry. (196; ch. 15)

Many readers of the novel probably remember this hand, and the feeling it once excited in their own hands as they read (as my students have obligingly confirmed). The emphasis (the italicized phrase) is in the original novel. And the rather Gothic fancy, characteristic of Dickens as we saw in Great Expectations, that Heep's is one of those faces on the beam-ends is only one of several suggestions in the novel of the way David's unconscious takes on Heep-like qualities.

Heep's hand quickly becomes one of those defining details out of which Dickens constructs character. As David gets to know Heep, he says at one point: "I suppose you are quite a great lawyer?"

"Me, Master Copperfield?” said Uriah. "Oh, no! I'm a very umble person."

It was no fancy of mine about his hands, I observed; for he frequently

Vol. 32, No. 3, September 2015 
ground the palms against each other as if to squeeze them dry and warm, besides often wiping them, in a stealthy way, on his pocket-handkerchief. (203; ch.26)

Soon after, David adds, Uriah's hand "felt like a fish, in the dark" (205). In all these descriptions, as indeed throughout the novel, Dickens invites us to share the experience of David the narrator as he tells, even writes, his own story. But in these passages in particular, something else is happening: it is not simply the experience, but the sensation of the narrator that we share, through his hand. It is not abstract, but physical. ${ }^{7}$ Thus even when the theme of hands is not central to the import of the novel, as it certainly is in the case of Great Expectations, Dickens is keen to activate our responses to his characters. There may be no hidden plot device that is signalled by the hands, but these scenes, and the opposition of Wickfield with Heep in particular, dramatize and invite readers to experience for themselves the central conflict of David Copperfield.

A good deal of the recent research into mirror neurons concerns perception of hand actions, how we respond to them in others and how we use them ourselves, consciously or not. One conference of March 24, 2012 entitled "Being Human," sponsored by the University of California and reported in Greater Good, the UC Berkeley journal that publicizes science online, explored the topic. V. S. Ramachandran's presentation to the conference explained that:

people with a phantom limb have a strong propensity to experience others' pain as their own [...] When most of us see someone get hurt, mirror neurons in our brains fire in such a way to suggest that we ourselves are experiencing their pain. But our skin knows better. It doesn't send any signal of being hurt (because it's not), and it serves to 'veto' the signal sent by the mirror neurons [...] But when people are missing a limb, there's no skin to veto the brain's signal and indicate that the pain's not real. So when people with a phantom limb observe someone else getting hurt (like by getting pricked in the finger), they feel and react as if they themselves have been hurt - they say 'ouch' and pull back their hand.

That seems a helpful way to describe what works of art do to us. Unless you are missing the relevant limb, you will not say "ouch" but you will, nevertheless, have the experience. ${ }^{8}$ Knowing about this neurological research

7 For a persuasive application of neuronal research to the experience of reading George Eliot and Dostoevsky, see Maryanne Wolf, Proust and the Squid: The Story and Science of the Reading Brain (Cambridge: Icon Books, 2008).

8 I have explored the literature about phantom limbs and related matters in "Hands On." See also Oliver Sacks, 277-80. 
will not necessarily change our reaction to such passages as those I have been quoting, but it may well make us a little more conscious of the ways we read and react. The neurologists have added a further, physical layer of explanation for our responses to the hands of a skilful, deliberately sensuous writer like Dickens.

\section{WORKS CITED}

Bolens, Guillemette. The Style of Gestures: Embodiment and Cognition in Literary Narrative. Baltimore: Johns Hopkins UP, 2012.

Capuano, Philip. "Handling the Perceptual Politics of Identity in Great Expectations." Dickens Quarterly 27.3 (September 2010): 185-208.

Dickens, Charles. David Copperfield. Ed. Jerome H. Buckley. Norton Critical Edition. New York: Norton, 1990.

-. Great Expectations. Norton Critical Edition. Ed Edgar Rosenberg. New York, Norton, 1999.

Forker, Charles R. "The Language of Hands in Great Expectations." Texas Studies in Literature and Language 3 (1961): 280-93.

Forsyth, Neil. 2015. "Hands On." A Concise Companion to The Study of Manuscripts, Printed Books, and The Production of Early Modern Texts. Ed. Edward Jones. Oxford: John Wiley, 2015. 294-321.

Gallese Vittorio. "The Roots of Empathy: The Shared Manifold Hypothesis and The Neural Basis of Intersubjectivity."' Psychopathology 36 (2003):171-80.

Hennard Dutheil de la Rochère, Martine. "Great Expectations as Reading Lesson." Dickens Quarterly 13:3 (1996): 164-74.

Hornback, Bert G. Great Expectations: A Novel of Friendship. Boston: Twayne, 1987.

Jordan, Joseph P. Dickens Novels as Verse. Lanham: Farleigh Dickinson UP, 2012.

Kellogg, David. "'My Most Unwilling Hand': The Mixed Motivations of David Copperfield." Dickens Studies Annual 20 (1991): 57-73.

Macleod, Norman. "Which Hand? Reading Great Expectations as a Guessing Game." Dickens Studies Annual 31 (2002): 127-57.

Ramachandran, V. S. 2012. In Jason Marsh, "Notes on Being Human." http:// greatergood.berkeley.edu/article/item/notes_on_being_human.

Sacks, Oliver. Hallucinations. New York: Knopf, 2012.

Tallis, Raymond. Aping Mankind: Neuromania, Darwinitis and the Misrepresentation of Mankind. Durham: Acumen, 2011.

Wolf, Maryanne. Proust and the Squid: The Story and Science of the Reading Brain. Cambridge: Ice on Books, 2008.

Yeatman, J. D. Et al. 2014. "The vertical occipital fasciculus: A century of controversy resolved by in vivo measurements." Publications of the National Academy of Sciences, DOI: $10.1073 /$ pnas. 1418503111.

Vol. 32, No. 3, September 2015 